\title{
First record of Euxestonotus error (Hymenoptera: Platygastridae) in the Pacific Northwest, United States of America
}

\section{Authors: Erik R Echegaray, RN Stougaard, and B Bohannon}

This is a postprint of an article that originally appeared in Canadian Entomologist on October 2016. https://dx.doi.org/ 10.4039/tce.2016.8

Echegaray, E R, R N Stougaard, and B Bohannon. "First record of Euxestonotus error (Hymenoptera: Platygastridae) in the Pacific Northwest, United States of America." Canadian Entomologist 148, no. 5 (October 2016): 616-618. DOI: 10.4039/tce.2016.8. 


\title{
First record of Euxestonotus error (Hymenoptera: Platygastridae) in the Pacific Northwest, United States of America
}

\author{
E.R. Echegaray, ${ }^{1}$ R.N. Stougaard, B. Bohannon
}

\begin{abstract}
Euxestonotus error (Fitch) (Hymenoptera: Platygastridae) is considered part of the natural enemy complex of the wheat midge Sitodiplosis mosellana (Géhin) (Diptera: Cecidomyiidae). Although previously reported in the United States of America, there is no record for this species outside the state of New York since 1865. A survey conducted in the summer of 2015 revealed that E. error is present in northwestern Montana and is likely playing a role in the suppression of wheat midge populations.
\end{abstract}

Wheat (Triticum Linnaeus; Poaceae) is a major agricultural crop globally and the third most important crop in the United States of America with $\sim 22.7$ million ha planted every year. Spring wheat acres comprise $20-23 \%$ of the total United States of America wheat growing area and are concentrated in the northern Great Plains and Pacific Northwest regions (Vocke and Ali 2013). While wheat production areas are found throughout most of the country, the Pacific Northwest, including northwestern Montana, represents 13\% of the total spring wheat production with an average yield of 60 bushels per acre (Vocke and Ali 2013; United States Department of Agriculture-National Agriculture Statistics Service and Montana Department of Agriculture 2014).

Among spring wheat pests, the wheat midge, Sitodiplosis mosellana (Géhin) (Diptera: Cecidomyiidae) is one of the most destructive. Annually, economic losses associated with this pest in Canada have been estimated in the millions of Canadian dollars (Olfert et al. 1985). An outbreak in Flathead County, Montana during 2006 resulted in more than 1.5 million US dollars in lost revenue (Stougaard et al. 2014). Therefore, severe infestations have an enormous impact on wheat production and farm income.

Current management tactics against the wheat midge primarily consist of resistant varieties and insecticides (Chavalle et al. 2015). However, biocontrol agents also play an important role in suppressing wheat midge populations. The effectiveness of the European egg-larval parasitoid Macroglenes penetrans (Kirby) (Hymenoptera: Pteromalidae) in North America is well documented (Doane et al. 1989; Doane and Olfert 2008; Olfert et al. 2009). In addition, two Platygastridae (Hymenoptera) species, Platygaster tuberosula Kieffer and Euxestonotus error (Fitch) (previously classified as Platygaster error) are known to parasitise the wheat midge (Doane et al. 1989; Olfert et al. 2003; Chavalle et al. 2015). Although E. error has been reported in western Canada, current available information on its effectiveness and distribution are minimal (Doane and Masner 1991; Chavalle et al. 2015).

While there is no evidence of the presence of $P$. tuberosula in the United States of America, E. error has been reported in the state of New York (Fitch 1865: 818). However, there is no record for this species outside the northeastern portion of the United States of America. Masner (1989) suggested that introduction of this species into the United States of America might have been accidental which would explain why it is poorly established. No wheat midge parasitoids have been found in surveys previously conducted in the Pacific Northwest (Reeher 1945) or northeastern Montana (Shanower 2005). 
A field survey was conducted in Flathead County, in northwestern Montana, during the summer of 2015. Sweep net samples were collected every three to four days between June 19 and July 16 from spring wheat fields in eight different locations throughout the county. Each sample consisted of 100 consecutive sweeps, swinging the net each step $180^{\circ}$, and following a linear transect from the edge towards the centre of the field. Four sites were located in the eastern and southern portion of the county: Site $1\left(48.1924^{\circ} \mathrm{N}\right.$, $\left.114.135^{\circ} \mathrm{W}\right)$, Site $2\left(48.1041^{\circ} \mathrm{N}, 114.184^{\circ} \mathrm{W}\right)$, Site $3\left(48.0921^{\circ} \mathrm{N}, 114.131^{\circ} \mathrm{W}\right)$, and Site 4 $\left(48.2114^{\circ} \mathrm{N}, 114.158^{\circ} \mathrm{W}\right)$, and four sites in the western part of the county: Site $5\left(48.2505^{\circ} \mathrm{N}\right.$, $\left.114.309^{\circ} \mathrm{W}\right)$, Site $6\left(48.3633^{\circ} \mathrm{N}, 114.285^{\circ} \mathrm{W}\right)$, Site $7\left(48.3091^{\circ} \mathrm{N}, 114.379^{\circ} \mathrm{W}\right)$, and Site 8 $\left(48.3606^{\circ} \mathrm{N}, 114.439^{\circ} \mathrm{W}\right)$. Samples were stored separately in $3.8-\mathrm{L}$ (1 gallon) plastic bags at $2-8^{\circ} \mathrm{C}$ until processed. Parasitoids were sorted and counted under the microscope.

Hymenoptera species, including $M$. penetrans and at least one platygastrid species were the most abundant. The total number of platygastrids per location were $48,1362,12,24,5,42,21$, and 77 from Site 1, Site 2, Site 3, Site 4, Site 5, Site 6, Site 7, and Site 8, respectively. Four specimens collected from Site 2 on 29 June 2015 were sent to the United States Department of AgricultureAgriculture Research Service, Systematic Entomology Laboratory (Washington, District of Columbia, United States of America), and were identified as Euxestonotus error. Voucher specimens are deposited at the Smithsonian National Museum of Natural History in Washington District of Columbia, United States of America. Following a survey conducted in 2014, 40-100\% parasitism was found in cocoons. Although the highest parasitism may be attributed to $M$. penetrans, platygastrids including E. error may be playing a role in the suppression of wheat midge populations in Flathead County and possibly across other wheat-producing areas of the Pacific Northwest and Northern Great Plains. Since E. error has not been released in this area it is possible that existing populations have arrived via migration. To our knowledge, this is the first record of E. error in the Pacific Northwest including northwest Montana.

\section{Acknowledgements}

The authors thank Dr. Matthew Buffington and Dr. Elijah Talamas from the Systematic Entomology Laboratory, United States Department of Agriculture-Agriculture Research Service for the identification of the species and Dr. Héctor Cárcamo from Agriculture and Agri-Food Canada for reviewing this manuscript.

\section{References}

Chavalle, S., Buhl, P.N., Censier, F., and De Proft, M. 2015. Comparative emergence phenology of the orange wheat blossom midge, Sitodiplosis mosellana (Géhin) (Diptera: Cecidomyiidae) and its parasitoids (Hymenoptera: Pteromalidae and Platygastridae) under controlled conditions. Crop Protection, 76: $114-120$.

Doane, J.F., DeClerck-Floate, R., and Arthur, A.P. 1989. Description of the life stages of Macroglenes penetrans (Kirby) (Hymenoptera: Chalcidoidea, Pteromalidae), a parasitoid of the wheat midge, Sitodiplosis mosellana (Géhin) (Diptera: Cecidomyiidae). The Canadian Entomologist, 121: 1041-1048.

Doane, J.F. and Masner, L. 1991. Discovery of the wheat midge parasitoid, Euxestonotus error (Fitch) (Hymenoptera: Platygasteridae), in British Columbia. Biocontrol News, 5: 50-51.

Doane, J.F. and Olfert, O. 2008. Seasonal development of wheat midge, Sitodiplosis mosellana (Géhin) (Diptera: Cecidomyiidae), in Saskatchewan, Canada. Crop Protection, 27: 951-958.

Fitch, A. 1865. Noxious and other insects of the state of New York. Insects infesting grain crops, 6th report. C. van Benthuysen, Albany, New York, United States of America.

Masner, L. 1989. Euxestonotus error (Fitch) Palearctic or Nearctic? Biocontrol News, 2: 23-24.

Olfert, O., Doane, J.F., and Braun, M.P. 2003. Establishment of Platygaster tuberosula, and introduced parasitoid of the wheat midge, Sitodiplosis mosellana. The Canadian Entomologist, 135: 303-308.

Olfert, O., Elliott, R.H., and Hartley, S. 2009. Non-native insects in agriculture: strategies to manage the economic and environmental impact of wheat midge, Sitodiplosis mosellana, in Saskatchewan. Biological Invasions, 11: 127-133.

Olfert, O., Mukerji, M.K., and Doane, J.F. 1985. Relationship between infestation levels and yield loss caused by wheat midge, Sitodiplosis mosellana (Géhin) (Diptera: Cecidomyiidae), in spring wheat in Saskatchewan. The Canadian Entomologist, 117: 593-598. 
Reeher, M.M. 1945. The wheat midge in the Pacific Northwest. Circular, United States Department of Agriculture, 732: 1-8.

Shanower, T.G. 2005. Ocurrence of Sitodiplosis mosellana (Diptera: Cecidomyiidae) and its parasitoid, Macroglenes penetrans (Hymenoptera: Platygasteridae), in northeastern Montana. The Canadian Entomologist, 137: 753-755.

Stougaard, R.N., Bohannon, B., Picard, D., Reddy, G. V.P., Talbert, L., Wanner, K., et al. 2014. Orange wheat blossom midge. Montana State University Extension, Bozeman, Montana, United States of America.
United States Department of Agriculture-National Agriculture Statistics Service and Montana Department of Agriculture. 2014. Montana 2014 agricultural statistics [online]. Available from http://www.nass.usda.gov/ Statistics_by_State/Montana/Publications/Annual_ Statistical_Bulletin/2014/Montana_Annual_Bulletin_ 2014.pdf [accessed 30 November 2015].

Vocke, G. and Ali, M. 2013. U.S. wheat production practices, costs, and yields: variations across regions [online]. United States Department of AgricultureEconomic Research Service. Available from http://www.ers.usda.gov/media/1182541/eib116_ summary.pdf [accessed 30 November 2015]. 